\title{
ПЕРСПЕКТИВЫ ИСПОЛЬЗОВАНИЯ ПРИРОДНОГО ГАЗА В КАЧЕСТВЕ МОТОРНОГО ТОПЛИВА
}

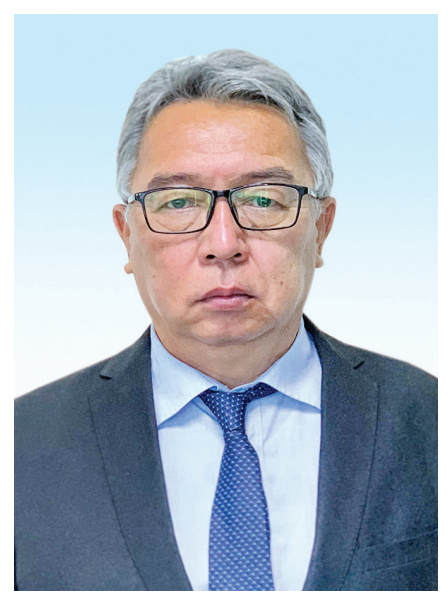

T.C. АРЫСТАНБАЕВ ${ }^{1,2 *}$, директор департамента корпоративного развития и управления активами, и.о. председателя правления

ОЮЛ «Газомоторная ассоциация Казахстана», https://orcid.org/0000-00024926-5208

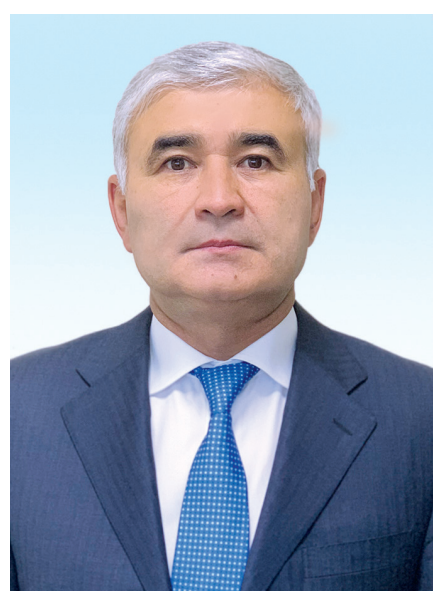

A.C. АШИРОВ ${ }^{1}$, генеральный директор (председатель правления), https://orcid.org/0000-00027972-5287

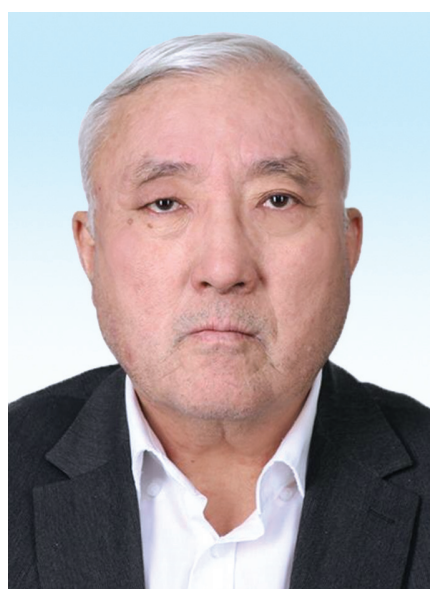

E.K. TOXTAPOB ${ }^{1,2}$, заместитель председателя НТС, исполнительный директор ОЮЛ «Газомоторная ассоциация Казахстана», https://orcid.org/0000-00026276-9152

'ТОО «КАЗТРАНСГАЗ ОНІМДЕРІ»,

Республика Казахстан, г. Нур-Султан, ул. А. Бокейхан, зд. 12

2ОЮЛ «ГАЗОМОТОРНАЯ АССОЦИАЦИЯ КАЗАХСТАНА»,

Республика Казахстан, г. Алматы, ул. Байзакова, 280

Рассматриваются проблемы развития рынка природного газа (метан) в качестве моторного топлива в Республике Казахстан для обеспечения национальных и международных транзитных автоперевозчиков сжиженным и компримированным природным газом (СПГ/КПГ). В статье сделан анализ выполнения стратегии развития рынка газомоторного топлива (ГМТ) в РК, описание его технологических, экологических и экономических характеристик и преимуществ по сравнению с традиционными видами моторного топлива, исследуются основные задачи и риски по строительству производственно-сбытовой инфраструктуры СПГ/КПГ на «Международном транспортном маршруте «Европа-Китай» (МТМ Е-К). Акцентируется внимание на актуальной необходимости проведения исследования текущей и прогнозной интенсивности движения газомоторной техники по МТМ E-К, совершенствования нормативных документов, регулирующих эти транзитные потоки, даны предложения по механизму их формирования, оптимизации

* Адрес для переписки. E-mail: t.arystanbayev@ktgo.kz 
структуры рынка ГМТ в РК. В этих целях обосновываются первоочередные задачи по проведению научно-технических, экономических и экологических исследований в данной сфрере, необходимых для задействования механизма расширения транзита газомоторного потока на МTM E-К, расчета социально-экономических эффректов для экономики $P K$, подтверждающих соответствие рассматриваемых задач по газификации МТМ Е-К международным инициативам «Один пояс - один путь» и целям плана сотрудничества по сопряжению Новой экономической политики «Нұрлы Жол» и строительства "Экономического пояса Шелкового пути".

КЛЮЧЕВЫЕ СЛОВА: сжиженный и компримированный природный газ, газомоторное топливо, газомоторные автомобили, снижение вредных выбросов и парниковых газов от транспорта, экология, стратегия низкоуглеродного развития, якорный потребитель, комплексный план, инновационная технология, инвестиции, международный транспортный марирут, интенсивность движения газомоторной техники, автопробег.

\title{
ТАБИҒИ ГАЗДЫ МОТОР ОТЫНЫ РЕТІНДЕ ПАЙДАЛАНУ ПЕРСПЕКТИВАЛАРЫ
}

T.C. АРЫСТАНБАЕВ ${ }^{1,2}$, корпоративтік даму және активтерді басқару департаментінің директоры, «Қазақстанның газ мотор қауымдастығы» ЗТБ Басқарма төрағасының м.a, https://orcid.org/00000002-4926-5208;

А.С. АШИРОВ ${ }^{1}$, бас директор (Басқарма төрағасы), https://orcid.org/0000-0002-7972-5287;

E.К. TOXTAPOB ${ }^{1,2}$, ҒТК төрағасының орынбасары, «Қазақстанның газ мотор қауымдастығы» ЗТБ атқарушы директоры, https://orcid.org/0000-0002-6276-9152

\author{
${ }^{1}$ «ҚАЗТРАНСГАЗ ӨНІМДЕРІ» ЖШС, \\ Қазақстан Республикасы, Нұр-Сұлтан қ., Ә. Бөкейхан к-сі., 12 ғимарат \\ «КАЗАҚСТАННЫН ГАЗ МОТОР ҚАУЫМДАСТЫҒЫ» ЗТБ, \\ Қазақстан Республикасы, Алматы қ., Байзақов к-сі, 280,
}

Ұлттық және халықаралық транзиттік автотасымалдаушыларды сұйытылған және сығылған табиғи газбен (СТГ/Сығылған ТГ) қамтамасыз ету үшін Қазақстан Республикасында мотор отыны ретінде табиғи газ (метан) нарығын дамыту проблемалары қарастырылуда. Мақалада ҚР-дағы газ мотор отыны нарығын (ГМТ) дамыту стратегиясының орындалуына талдау жасалды, оның технологиялық, экологиялық және экономикалық сипаттамалары мен дәстүрлі мотор отыны түрлерімен салыстырғанда артықшылықтарының сипаттамасы жасалды, «Еуропа-Қытай» халықаралық көлік маршрутында (МТМ Е-К) СТГ/Сығылған ТГ өндірістік-өткізу инфрақұрылымын салу бойынша негізгі міндеттер мен негізгі тәуекелдер зерделенеді. Онда MTM Е-К бойынша газ моторлы техника қозғалысының ағымдағы және болжамды қарқындылығына зерттеу жүргізудің, осы транзиттік ағындарды реттейтін нормативтік құжаттарды жетілдірудің өзекті қажеттілігіне баса назар аударылады, оларды қалыптастыру тетігі, ҚР ГМТ нарығының құрылымын оңтайландыру бойынша ұсыныстар берілген. Осы мақсатта осы салада ғылыми-техникалық, экономикалық және экологиялық зерттеулер жүргізу жөніндегі бірінші кезектегі міндеттер негізделеді. Олар Е-К МTM-ге газ мотор ағыны транзитін кеңейту тетігін іске қосу, E-К МТМ-ді газдандыру жөніндегі қаралып отырған міндеттердің «Бір белдеу-бір жол» халықаралық бастамаларына және «Нұрлы Жол» Жаңа экономикалық саясатын ұштастыру жөніндегі ынтымақтастық жоспарының мақсаттарына және «Жібек жолының экономикалық белдеуін» салуға сәйкестігін растайтын ҚР экономикасы үшін әлеуметтік-экономикалық әсерлерді есептеу үшін қажет.

ТҮЙІн СӨзДЕР: сұйытылған және сығылған табиғи газ, газ мотор отыны, газ мотор автомобильдері, көліктен шығатын зиянды шығарындылар мен парниктік газдарды азайту, экология, төмен көміртекті даму стратегиясы, зәкірлі тұтынушы, кешенді жоспар, инновациялық технология, инвестициялар, халықаралық көлік бағыты, газ моторлы техника қозғалысының қарқындылығы, автошеру. 


\section{PROSPECTS FOR USING NATURAL GAS AS A MOTOR FUEL}

T.S. ARYSTANBAEV ${ }^{1,2}$, Director of the Department for Corporate Development and Asset Management, Acting Chairman of the Board of the ALE "Gas Engine Association of Kazakhstan", https://orcid.org/00000002-4926-5208;

A.S. ASHIROV', General Director (Chairman of the Management Board), https://orcid.org/0000-00027972-5287;

E.K. TOKHTAROV ${ }^{1,2}$, Deputy Chairman of the Research and Technical Council, Executive Director of ALE "Gas Engine Association of Kazakhstan", https://orcid.org/0000-0002-6276-9152

'LLC "KAZTRANSGAZUNIMDERI",

Republic of Kazakhstan, Nur-Sultan, A. Bokeikhan Street, bld. 12

${ }^{2}$ ALE "GAS ENGINE ASSOCIATION OF KAZAKHSTAN",

Republic of Kazakhstan, Almaty, Bayzakova Street, 280

The issues of the market development of the natural gas (methane) as a motor fuel in the Republic of Kazakhstan to provide national and international transit carriers with liquefied and compressed natural gas (LNG/CNG) have been reviewed. The article analyzes the implementation of the gas engine fuel market development strategy in Kazakhstan, describes its technological, environmental and economic characteristics and advantages in comparison with traditional types of motor fuels, studies the main tasks and key risks for the construction of LNG/CNG production and distribution infrastructure at the "International transport route "Europe-China" (ITR EC). It focuses on the urgent need to study the current and predicted traffic intensity of gas-engine vehicles according to ITR EC, improve the regulatory documents regulating these transit flows, give proposals on creation of such flows, and optimize the structure of the gas engine fuel market in Kazakhstan. For these purposes, the priority tasks for conducting scientific, technical, economic, and environmental research in this area have been identified. They are necessary for activating the mechanism for expanding the transit of gas engine flow at ITR EC, calculating socio-economic effects for the economy of Kazakhstan, confirming the compliance of the reviewed tasks on gasification of ITR EC with the international initiatives "One Belt-One Road" and the goals of the Cooperation Plan on linking the New Economic Policy "Nurly Zhol" and construction of the "Silk Road Economic Belt".

KEY WORDS: liquefied and compressed natural gas, gas engine fuel, gas-engine vehicles, reduction of harmful emissions and greenhouse gases from transport, ecology, low-carbon development strategy, anchor consumer, comprehensive plan, innovative technology, investments, international transport route, density of gas-engine vehicles traffic, auto rally.

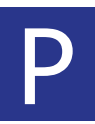
еспублика Казахстан занимает промежуточное положение между Российской Федерацией и Китайской Народной Республикой, располагает площадью 2,7 млн км², которая включает на западе некоторую часть Европейского континента, а центральной и южной частью входит в состав Центральной Азии. Уникальное срединное положение обеспечивает стране высокий транзитный потенциал, в связи с этим Правительство страны уделяет большое внимание развитию Транспортной стратегии, им принята программа инфраструктурного развития «Нурлы жол», Постановление Правительства РК №797 и другие документы. В них предусмотрено формирование на территории страны ряда транспортно-логистических хабов на основных транспортных транзитных направлениях [1], модернизация автотранспортного парка страны переводом его на использование экономичного и 
экологически чистого природного газа, создание условий по обеспечению данным моторным топливом транзитного грузового потока из автотранспортных средств, следующих по международному транспортному маршруту «Европа-Китай», пересекающего территорию Республики Казахстан [2].

Необходимо отметить, что в настоящее время на стадии утверждения Правительством РК также находится перечень проектов Министерства экологии, геологии и природных ресурсов РК, реализация которых обеспечивает сокращение выброса парниковых газов, позволяет определить на национальном уровне вклады различных секторов экономики в выполнение обязательств Казахстана по Парижскому соглашению. В этот перечень обоснованно включены проекты перевода автотранспорта и железнодорожных локомотивов национальной компании «Казахстан Темир Жолы» на сжиженный и компримированный природный газ.

Принимая во внимание планы «Международной академии наук Шелкового пути» о разработке специальной «Стратегии научно-технологического обеспечения развития проекта возрождения Шелкового пути» [3] и уникальное месторасположения Казахстана, позволяющего поддерживать транзитный грузопоток между Китаем и Европой в рамках инициативы «Один пояс - один путь», программа декарбонизация транспорта способствует получению весьма заметных экономических, экологических и социальных эффектов для стран, находящихся по маршруту Великого Шелкового пути.

В связи с вышеуказанным, актуальна инициатива оператора в этом секторе газовой отрасли ТОО «КазТрансГаз Өнімдері» и ОЮЛ «Газомоторная ассоциация Казахстана» по проведению исследования перспектив и возможности использования сжиженного и компримированного природного газа с целью создания благоприятных условий и повышения привлекательности казахстанского участка МТМ ЕК для международных, в том числе транзитных автоперевозчиков.

\section{О газомоторном топливе: перспективные виды газомоторного топлива в}

\section{РК. Технологические экологические и экономические преимущества}

Представленная в таблице 1 информация о свойствах и характеристиках применяемых в качестве моторного топлива газов, технологии их производства и рационального использования [2] является одной из определяющих для формирования всей дальнейшей стратегия развития рынка ГМТ в Казахстане и в мире в целом.

Для производства ГМТ применяется два вида газа:

- природный газ, основным компонентом которого является метан;

- углеводородный газ, состоящий преимущественно из пропан-бутановой смеси.

Из представленных трех видов газомоторного топлива в настоящее время КПГ и СУГ производятся и широко используются на транспорте, СПГ завозится из России.

Необходимо отметить, что агрегатное состояние, которое указано в названии ГМТ обеспечивает только способ транспортировки и хранения, но в камеру сгорания двигателя внутреннего сгорания (ДВС) указанное газомоторное топливо подается в нормальном газообразном состоянии под штатным давлением.

Уникальность производства КПГ заключается в том, что его производство и реализация осуществляются непосредственно на АГНКС. Здесь природный газ, поступивший на заправочную станцию из газопровода, подается в компрессор, 
Таблица 1 - Технологические характеристики видов газомоторного топлива

\begin{tabular}{|c|c|c|c|}
\hline Вид & Технология & Применение & Характеристика \\
\hline $\begin{array}{l}\text { Природный газ } \\
\text { Компримированный (КПП): } \\
\text { CNG }\left(\mathrm{CH}_{4}\right)\end{array}$ & $\begin{array}{l}\text { АГНКС - сжатие природного } \\
\text { газа до } 200 \text { бар, (уменьшение } \\
\text { по объему в } 200 \text { раз), } \\
\text { реализация. }\end{array}$ & $\begin{array}{l}\text { - Моторное топЛИвО - } \\
\text { ГОРОДСКИЕ } \\
\text { АВТОБУСЫ, } \\
\text { КОММУНАЛЬНАЯ } \\
\text { ТЕХНИКА }\end{array}$ & $\begin{array}{l}\text { - Экономия расходов на топливо в 2-3 раза } \\
\text { - Экологичность (Евро 5) } \\
\text { • Безопасное топливо (легче воздуха) }\end{array}$ \\
\hline $\begin{array}{c}\text { Природный газ Сжиженный } \\
(\mathrm{C} \Pi \text { : } \\
\operatorname{LNG}\left(\mathrm{CH}_{4}\right)\end{array}$ & $\begin{array}{l}\text { МТЗ - охлаждение природного } \\
\text { газа до - } 160^{\circ} \mathrm{C} \text { (уменьшение по } \\
\text { объему в } 600 \text { раз), } \\
\text { транспортировка КриоПАГЗ, } \\
\text { КриоАЗС реализация }\end{array}$ & $\begin{array}{l}\text { - Моторное топливо- } \\
\text { МАГИСТРАЛЬНЫЙ } \\
\text { ГРУЗОВОЙ } \\
\text { АВТОТРАНСПОРТ, } \\
\text { Ж/Д ЛОКОМОТИВЫ }\end{array}$ & $\begin{array}{l}\text { - Невозможность хищения } \\
\text { - Температура замерзания }-183^{\circ} \mathrm{C} \\
\text { - Октановое число CNG > 105, LNG > } 110 \text { до } 130\end{array}$ \\
\hline $\begin{array}{l}\text { Сжиженный } \\
\text { углеводородный газ (Суг): } \\
\text { LPG }\left(C_{3} H_{8}+C_{4} H_{10}\right)\end{array}$ & $\begin{array}{l}\text { НПЗ, ГПЗ - пропан-бутановая } \\
\text { смесь в сжиженном виде под } \\
\text { давлением } 16 \text { бар, } \\
\text { транспортировка вагон- } \\
\text { цистернами+автоцистерны, } \\
\text { АГЗС реализация }\end{array}$ & $\begin{array}{l}\text { - Моторное топЛИВо - } \\
\text { МАЛЬИЙ } \\
\text { КОММЕРЧЕСКИЙ И } \\
\text { ЛЕГКОВЫЕ } \\
\text { АВТОМОБИЛИ }\end{array}$ & $\begin{array}{l}\text { - Не применяется на большегрузном транспорте } \\
\text { (потеря мощности) } \\
\text { - Менее «экологичное», менее «безопасное» } \\
\text { моторное топливо в сравнении с природным } \\
\text { газом (тяжелее воздуха) } \\
\text { - ЦЦенный продукт для дальнейшей глубокой } \\
\text { переработки }\end{array}$ \\
\hline \multicolumn{4}{|c|}{$\begin{array}{ll}\text { АГНКС - } & \text { автомобильная газонаполнительная компрессорная станция. } \\
\text { МТЗ - } & \text { малотоннажный завод по производству СПГ. } \\
\text { КриоПАГЗ - передвижной криогенный автогазозаправщик. } \\
\text { КриоАЗС - } \\
\text { Ариогенная автомобильная заправочная станция. } \\
\text { АГЗ - } \quad \text { автомобильная газозаправочная станция }\end{array}$} \\
\hline
\end{tabular}

в котором под давлением в 200 атмосфер происходит его сжатие и уменьшение в объеме в 200 раз. Компримирование газа позволяет обеспечивать его эффективное хранение и использование в виде моторного топлива локальным городским автотранспортом, чаще всего автобусами, такси и коммунально-дорожными автомобилями.

Для производства и использования СПГ в качестве моторного топлива чаще используются малотоннажные заводы с инновационными криогенными технологиями (MT3), где природный газ при охлаждении до минус $163 \mathrm{C}^{\circ}$ сжижается и уменьшается в объеме в 600 раз. Возможность размещения большого объема СПГ в топливном криогенном баке (работает по принцииу термоса) грузового транспортного средства обеспечивает ему большие пробеги на одной заправке, что обосновывает целесообразность и эффективность его использования на железнодорожном и дальнобойном магистральном автомобильном транспорте. КриоПАГЗы транспортируют СПГ от МТЗ до КриоАЗС для дальнейшей реализации потребителям.

СУГ является продуктом переработки нефти. Более простая технология производства обеспечила ему широкое применение в народном хозяйстве, в том числе для дальнейшего передела в нефтехимии. Как ГМТ он применяется в основном на легковом и малом коммерческом автотранспорте из-за частичной потери мощности ДВС. СУГ теряет эксплуатационные свойства при температурах ниже минус 5 до минус $40 \mathrm{C}^{\circ}$ в зависимости от состава компонентов, из-за чего стандартами регулируется его качество для использования в летний и зимний период.

Кроме выше сказанного, преимущества природного газа перед другими видами моторного топлива обусловлены также иными его свойствами.

Природный газ более безопасен по сравнению с нефтяными видами топлива и СУГ, так как легче воздуха, в связи, с чем при утечке он быстро улетучивается, 
не образуя взрывоопасную газовоздушную смесь. Природный газ в сжиженном состоянии не горит, а быстро испаряется. В отличие от этого СУГ тяжелее воздуха, при утечке способен скапливаться внизу с образованием взрывоопасных концентраций с воздухом. К сожалению, данный факт повлиял на принятие уполномоченным органом по пожарной безопасности некорректного решения о запрете въезда в крытые помещения и подземные паркинги (с надлежащей вентиляцией) всех газомоторных автомобилей, в том числе использующих газомоторное топливо на метане, как КПГ и СПГ.

Природный газ дешевле в 2-3 раза традиционных нефтяных видов моторного топлива что позволяет сокращать расходы и экономить бюджеты различных уровней. Ассоциация NGV Global в целях обобщения международного опыта провела исследования в Аргентине, где замена дизельного топлива на природный аргентинский сланцевый газ позволила сэкономить для аргентинской экономики свыше трех миллиардов долларов, что вдвое выше тех средств, которые были инвестированы на производство сланцевого газа [5] (таблица 2). Природный газ, замерзающий при сверхнизких криогенных температурах, является всесезонным топливом, невозможность его хищения обеспечивает прозрачность учета его расходов. Однако, эти экономические преимущества в настоящее время, по различным причинам, не стали еще играть важное значение при выборе потребителями моторных топлив.

Таблица 2 - Экономические преимущества природного газа

\begin{tabular}{|c|c|c|c|c|c|c|c|c|c|c|c|c|c|c|c|c|}
\hline \multicolumn{13}{|c|}{ Сравнение затрат на 100 км пробега транспортного средства по видам топлива, с ндС } & & & & \\
\hline \multirow{2}{*}{$\begin{array}{c}\begin{array}{c}\text { Cronмость } \\
\text { топлива }\end{array} \\
\begin{array}{c}\text { Enд } \\
\text { транспорта }\end{array}\end{array}$} & \multicolumn{2}{|c|}{ Cnr: 150 Teнre/kr } & \multicolumn{2}{|c|}{ кпг: 80 тенге/цуб.M. } & \multicolumn{2}{|c|}{ 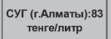 } & \multicolumn{2}{|c|}{$\begin{array}{l}\text { Летнеe वा: } 195 \\
\text { тенгеe/литр }\end{array}$} & \multicolumn{2}{|c|}{$\begin{array}{c}\text { Зимнее ДТ (-25 C): } 275 \\
\text { тенге/литтр }\end{array}$} & \multicolumn{2}{|c|}{$\begin{array}{c}\text { Бензин АИ-92: } 160 \\
\text { тенге/литр }\end{array}$} & \multirow{8}{*}{\multicolumn{4}{|c|}{$\begin{array}{l}\text { Международный опыт. Аргентина. Ассоциация NGV Global провела } \\
\text { исследования, для того чтобы сравнить преимущества использования } \\
\text { природного газа по сравнению с дизлем. Замена дизельного толива на } \\
\text { природный аргентинский сланцевый газ позволила сэкономить для } \\
\text { аргентинской экономики свыше трех миллиардов долларов, что вдвое } \\
\text { выше тех средств, которые были инвестированы на производство } \\
\text { сланцевого газа. } \\
\text { Экономические науки №26-1, } 31.10 .2014 \\
\text { Сравнения расчетного тарифа на перевозку 1-го пассажира автобусами, } \\
\text { использующими в качестве моторного топлива дТ и кПг для парка 200 } \\
\text { автобусов, с ндс }\end{array}$}} \\
\hline & \begin{tabular}{|c|} 
Pacxon \\
$\mathrm{w} / 100 \mathrm{kM}$
\end{tabular} & $\begin{array}{c}\text { 3атраты в } \\
\text { тенге на } \\
100 \text { на }\end{array}$ & $\begin{array}{c}\text { Pacxog } \\
\text { кy6.....1100 } \\
\text { kM }\end{array}$ & $\begin{array}{c}\text { Затраты } \\
\text { в тенге } \\
\text { на } 100 \mathrm{~km}\end{array}$ & $\begin{array}{c}\text { Расходы } \\
\text { лигр/100 } \\
\text { кM }\end{array}$ & $\begin{array}{c}\text { Затраты } \\
\text { в тенге } \\
\text { на } 100 \mathrm{~km}\end{array}$ & $\left|\begin{array}{c}\text { Расходы } \\
\text { литр/100 } \\
\text { кMM }\end{array}\right|$ & $\begin{array}{c}\text { 3атраты } \\
\text { e retre } \\
\text { Ha } 100 \\
\text { kM }\end{array}$ & $\begin{array}{c}\text { Расходы } \\
\text { литр/100 } \\
\text { кM }\end{array}$ & $\begin{array}{c}\text { Затраты в } \\
\text { тенге на } 100 \\
\text { кM }\end{array}$ & $\begin{array}{c}\text { Раскоды } \\
\text { литр/100 } \\
\text { кM }\end{array}$ & $\mid \begin{array}{c}\text { 3атраты в } \\
\text { тенге на } \\
100 \text { нам }\end{array}$ & & & & \\
\hline Автобус & 29 & 4317 & 40 & 3200 & не приме & енняегся & 40 & 7800 & 40 & 11000 & 44 & 7040 & & & & \\
\hline Грузовой & 29 & 4317 & 40 & 3200 & не приите & иеняетсся & 40 & 7800 & 40 & 11000 & 44 & 7040 & & & & \\
\hline Легковой & 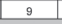 & 1295 & 12 & 960 & 13 & 975 & 10 & 1950 & 10 & 2750 & 11 & 1760 & & & & \\
\hline \multicolumn{5}{|c|}{ Рост затрат на топливо в сравиении с Кпг, \% } & \multicolumn{2}{|c|}{$102 \%$} & \multicolumn{2}{|c|}{$244 \%$} & \multicolumn{2}{|r|}{$344 \%$} & \multicolumn{2}{|c|}{$220 \%$} & & & & \\
\hline \multicolumn{7}{|c|}{ Рост затрат на топливо в сравнении с с $\mathrm{C}$, $\%$} & \multicolumn{2}{|c|}{$181 \%$} & \multicolumn{2}{|r|}{$255 \%$} & \multicolumn{2}{|c|}{$163 \%$} & & & & \\
\hline \multirow{2}{*}{\multicolumn{13}{|c|}{$\begin{array}{l}\text { Сравнения расчетного тарифа на перевозку 1-го пассажира автобусами, использующими в качестве моторного } \\
\text { топлива ДТ и КПГ дпя парка } 200 \text { автобусов, с НДС }\end{array}$}} & & & & \\
\hline & & & & & & & & & & & & & Показатели & Едизм & дт & knг \\
\hline \multirow{2}{*}{\multicolumn{5}{|c|}{ Наименование показателя }} & \multicolumn{6}{|c|}{ Дизельное топливо } & \multirow{2}{*}{\multicolumn{2}{|c|}{ кпг }} & Перк новых автобу сов & en. & 200 & 200 \\
\hline & & & & & \multirow{2}{*}{\multicolumn{2}{|c|}{\begin{tabular}{|c|} 
Aт (средннегодовов) \\
228
\end{tabular}}} & \multirow{2}{*}{\multicolumn{2}{|c|}{$\begin{array}{l}\text { ДТ (петнее) } \\
195\end{array}$}} & \multirow{2}{*}{\multicolumn{2}{|c|}{$\begin{array}{l}\text { Діг (зиннее) } \\
275\end{array}$}} & & & Субсидия в год на весь перк & Tetre & 5908320763 & 4115545902 \\
\hline \multicolumn{3}{|c|}{ Цена топлива, тенге } & & & & & & & & & \multicolumn{2}{|c|}{80} & Годовая экономияя по суб̆сидиям & Terre & 17927 & 84861 \\
\hline \multicolumn{3}{|c|}{ Годсвой пробег автобуса, ки. } & & & \multicolumn{2}{|c|}{75000} & \multicolumn{2}{|c|}{56250} & \multicolumn{2}{|c|}{18750} & & 5000 & Снижение нагрузки на бюджет PK за 5 лет & renre & 94828 & 78535 \\
\hline Затраты на то & эпливо для с с & одного автос & 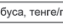 & & 6450 & 0000 & 43875 & 500 & & 062500 & & 00000 & Расходь на моторное топливо & тенге & 1994464286 & 625714286 \\
\hline Количество па а & арка автобус & сов, ед. & & & 120 & 000 & & & & & & 2000 & Годовая экономия по моторному топливу & тенге & 13687 & 50000 \\
\hline Затраты на то & опливо аля п & парка, тенrel & & & 774300 & 000000 & & & & & 28800 & 000000 & $\begin{array}{l}\text { Возврат инвестиции на закуп } 200 \text { газовых } \\
\text { автобусов }\end{array}$ & Trerre & 72400 & 00000 \\
\hline Затраты на то & эпливо на ср & оск спужбы 7 & 7 лот, тенге & & 541800 & 000000 & & & & & 201600 & 0000000 & \begin{tabular}{|l|} 
Onyпаемость газовых ветобусов \\
\end{tabular} & годы & & \\
\hline & & & экономия & Я затрат на & a тоnпиво: & $3 \mathrm{a} 7$ пет зкс & ксппуатаии - & ии. тенге & & 340200 & 00000 & & $\begin{array}{l}\text { Возврат инвестиции на зақуп } 200 \text { газовых } \\
\text { автобусов }\end{array}$ & rehre & 16722 & 78535 \\
\hline
\end{tabular}

Природный газ как более экологически чистый по сравнению с традиционными видами моторного топлива, оказывает менее отрицательное воздействие на окружающую среду, что также способствует улучшению состояния здоровья населения и экономии бюджетных средств на оздоровление населения (рисунок 1). По проведенным исследованиям Всемирного банка сокращение уровня концентрации твердых частиц хотя бы на 1 мгм/м³ приведет к ежегодной экономии в 57 млн долл. США в сфере здравоохранения за счет сокращения преждевременной смертности и повышения производительности труда и меньшего количества больничных листов [6]. Замещение бензина и дизельного топлива природным газом снижает не только 


\section{БУДУЩЕЕ НЕФТЕГАЗОВОГО КОМПЛЕКСА}

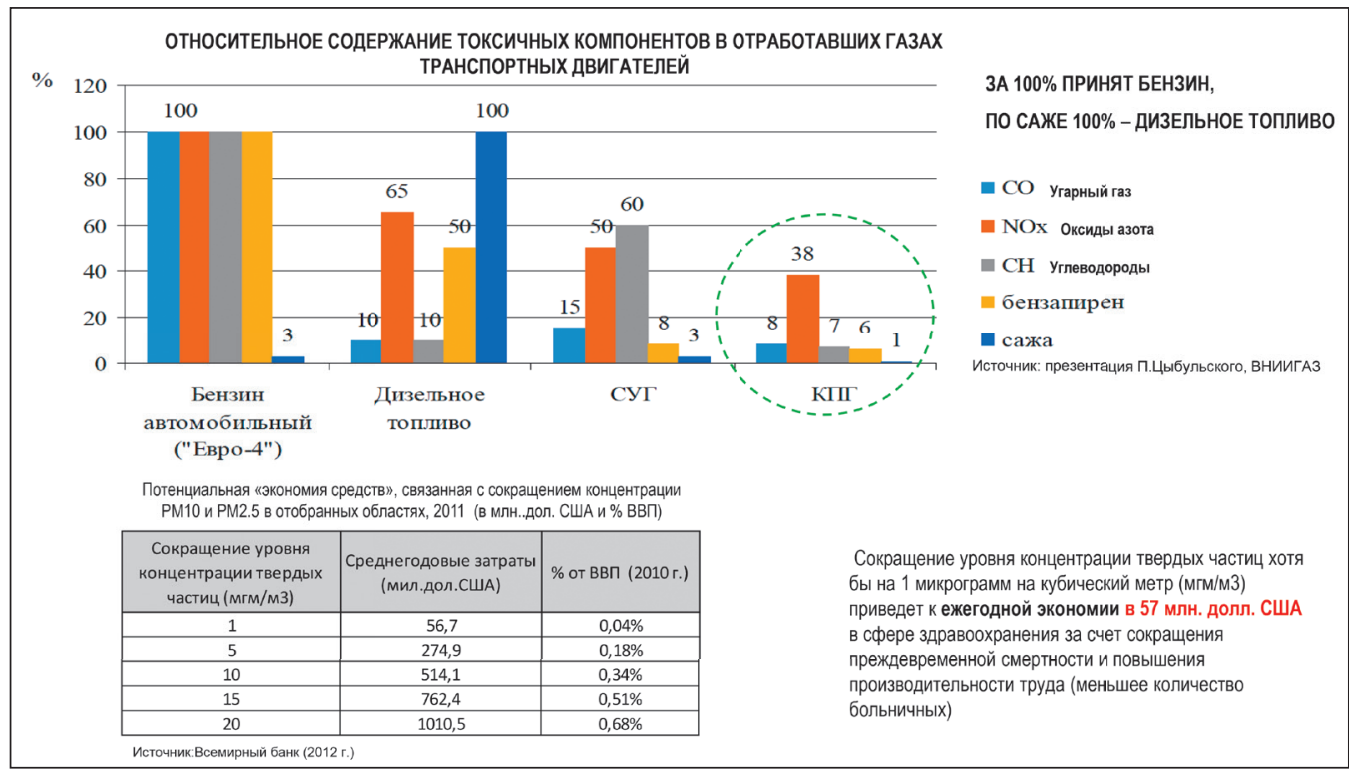

Рисунок 1 - Экологические преимущества природного газа

вредные выбросы, но и выбросы парниковых газов [7]. В связи с этим при разработке проекта Стратегии низкоугеродного развития РК по заданию Правительства и МЭГиПР РК АО «Жасыл Даму» включило проекты по переводу автомобильного и железнодорожного транспорта на природный газ в Дорожную карту определяемых на национальном уровне вкладов (ОНУВ) в сокращение выбросов парниковых газов от различных секторов экономики Казахстана на период 2025-2030 гг. Необходимо отметить, что в настоящее время в мировой практике нередко используются технологии L-CNG, позволяющие из СПГ, полученного на КриоАЗС, производить способом регазификации высококачественный КПГ (лучше, чем прямым компримированием на АГНКС) при минимальных капитальных вложениях [8].

Просчитано, что при отнесении суммарных расходов по производству СПГ на заводе и транспортировке до КриоАЗС на стоимость выдачи СПГ на топливной колонке, себестоимость КПГ соответствует расходам на электроэнергию насоса высокого давления (поз. 3 рисунок 2). При этом сохраняется экономическая привлекательность СПГ по сравнению с дизтопливом, а стоимость КПГ будет дешевле, чем на АГНКС, где используется мощное компрессорное оборудование.

Данную технологию планируется применить при создании инфраструктуры на МТM Е-K.

\section{Основания развития рынка ГМТ в РК}

С учетом вышеперечисленных преимуществ природного газа как газомоторного топлива для развития рынка ГМТ в РК становятся руководящие документы странового и международного уровня, перечисленные ниже. В каждом из них предусмотрены индикаторы и рекомендации по переводу транспортного сектора на использование природного газа в качестве моторного топлива. 


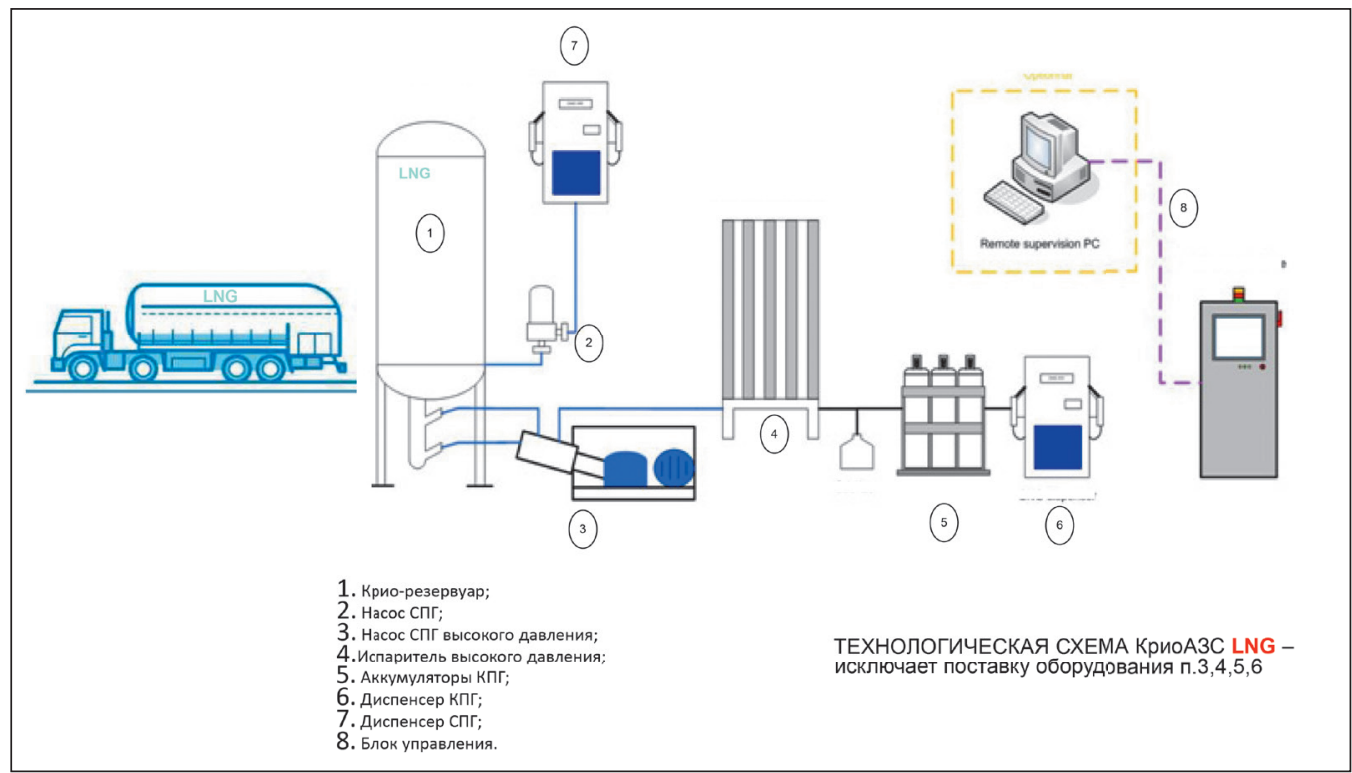

Рисунок 2 - Технология L-CNG (двух-топливная КриоАЗС)

Зеленым цветом выделены те документы, которые отражают положительные экологические свойства природного газа как моторного топлива.

Красным цветом выделен основной документ «План мероприятий по расширению использования природного газа в качестве моторного топлива на 2019-2022 годы», утвержденный Постановлением Правительства РК №797 от 29.11.2018 г. (далее План), по которому в настоящее время идет развитие рынка КПГ и СПГ в РК.

Необходимо отметить, что в октябре 2017 года подписан Меморандум между ПАО "Газпром", Китайской Национальной Нефтегазовой Корпорацией (CNPC) и АО "НК "КазМунайГаз", по которому в рамках трехсторонних Совместной и

«Концепция развития газового сектора РК до 2030 года»;

« «План мероприятий по реализации Государственной программы инфраструктурного развития "Нұрлы жол" на 2015-2019 годы».

】 «План мероприятий по реализации Концепции по переходу РК к «зеленой экономике» на 2013-2020 годы»;

口 «Программа «зеленых» инвестиций: поддержка экологически чистого городского общественного транспорта в Казахстане". ОЭСР

«Стимулирование использования природного газа в транспортном секторе: концепция: NAMА для низкоуглеродного развития Казахстана», зарегистрирована в Секретариате Рамочной конвенции по изменению климата ООН в качестве национальной программы РК;

口 Обзор политики развития сектора общественного транспорта в РК. Проект ПРООН-ГЭФ «Устойчивый транспорт г Алматы» 口 Стратегия низкоуглеродного развития РК до 2050 года. ОНУВ

П Проект Европейской экономической комиссия ООН «Улучшение возможностей стран-членов ЕЭК ООН по декарбонизации транспортного сектора за счет увеличения использования природного газа в качестве моторного топлива»

$\square$ «План мероприятий по расширению использования природного газа в качестве моторного топлива на 2019-2022 годы», утвержден Постановлением Правительства РК №797 от 29.11.2018г.

« «Комплексная программа (дорожная карта) по развитию автобусных перевозок на 2018-2020 годы» (замещена) на «Государственную программу развития туристской отрасли Республики Казахстан на 2019-2025 годы»;

- «Комплекс мер по развитию и стимулированию использования природного газа в качестве моторного топлива для транспортных средств государств-участников СНГ на период до 2025 года».

口 «План мероприятий по реализации первого этапа (2021-2025 годы) Стратегии экономического развития СНГ на период до 2030 года»;

口 Стратегический план Министерства индустрии и инфраструктурного развития РК на 2017-2021 годы.

- Меморандум о взаимопонимании по сотрудничеству в области развития производственно-сбытовой инфраструктуры природного газа к качестве моторного топлива на международном транспортном маршруте Европа-Китай, подписанный между ПАО Газпром, CNPC, АО НК КазМунайгаз 5 октября 2017г. 
Специальной рабочих групп активно ведется работа по проектам развития производственно-сбытовой инфраструктуры на МТМ Е-К, в том числе: исследование прогноза интенсивности движения газомоторной техники, изучение соответствующих технологии и расчет мощности производственно-сбытовой инфраструктуры, необходимый объем инвестиций в строительство этих объектов и разработку и/или унификацию НТД.

\section{Стратегия развития сети АГНКС/КРИО АЗС и производства СПГ}

Организационная структура стратегии развития рынка ГМТ с распределением ролей, ответственности и взаимодействия государственных органов, МИО, квазигоссектора и бизнеса представлена на рисунке 3.

Планом предусмотрено строительство 85 объектов производственно-сбытовой инфраструктуры, госзаказ отечественному автопрому на производство и поставку автоперевозчикам 12 тыс. единиц автобусов с газовыми двигателями и спецтехники, а также создание государством соответствующих благоприятных условий для представителей бизнеса, непосредственно инвестирующих финансовые средства:

- в строительство Производственно-сбытовой инфраструктуры, которая является зоной компетенции и ответственности газовой отрасли;

- в развитие Потребительской инфраструктуры, к которой относятся транспорт и объекты малой энергетики, отчего эта зона компетенции и ответственности транспортной отрасли и МИО;

- в формирование Сервисной инфраструктуры, роль которой не ограничивается только услугами сервиса, но в значительной степени связан с обеспечением безопасной эксплуатации транспортных средств, потребляющих ГМТ, данный сектор отчасти относится к транспортной отрасли.

Необходимо отметить, что ответственным за исполнение мероприятий Плана является межотраслевая рабочая группа, утвержденная приказом МЭ РК (МРГ).

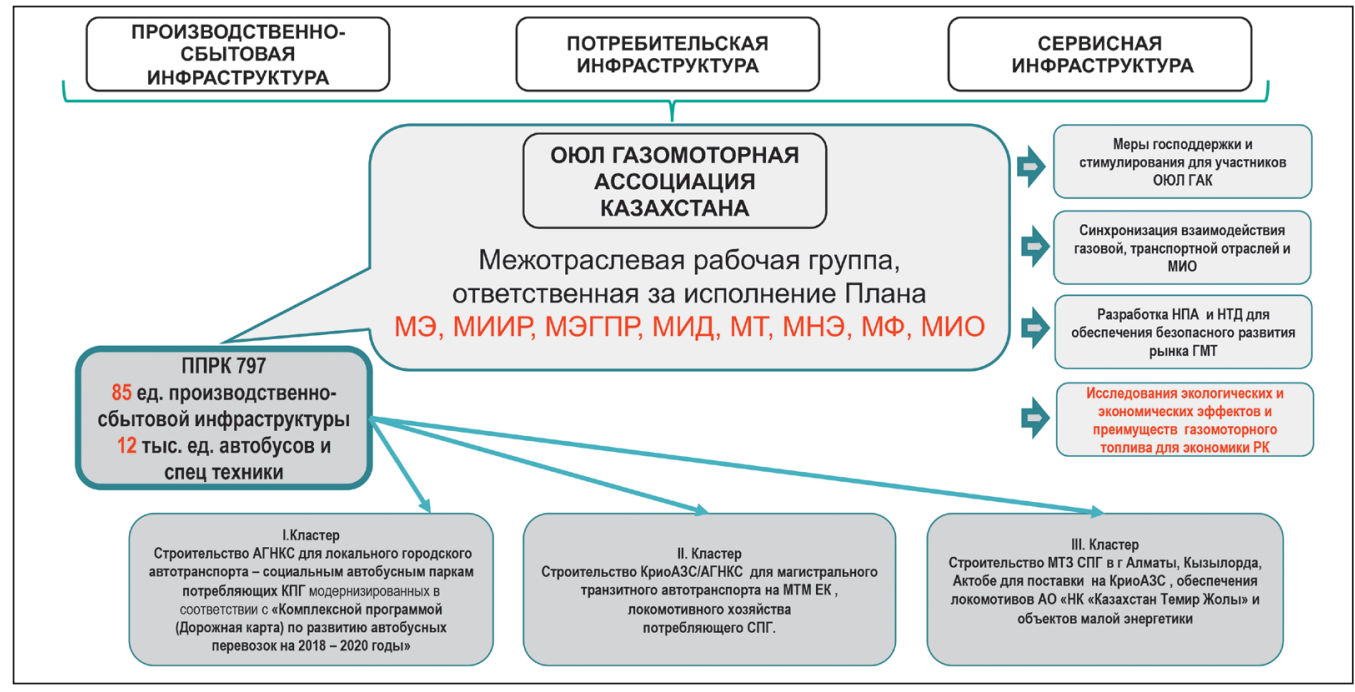

Рисунок 3 - Структура организационной стратегии рынка ГМТ 
В ее состав входят уполномоченные и местные исполнительные органы, финансовые институты и заинтересованные организации, где интересы участников рынка ГМТ представляет ОЮЛ ГАК.

По рекомендации МЭ РК в настоящее время активизируется роль ОЮЛ ГАК, перед которой поставлены задачи по координации взаимодействия всех участников рынка ГМТ в РК. В настоящее время ГАК направлены предложения в канцелярию Премьер-Министра РК (КПМ) по разработке и внедрению мер господдержки и преференции для участников рынка ГМТ в РК, на которые получены соответствующие поручения. На основании поручений актуализируется состав МРГ, формируется Дорожная карта с мероприятиями по синхронизации и безопасному развитию рынка ГМТ, в которые включены необходимые научно-технические и экономические исследования, позволяющие определить эффекты для экономики РК от развития рынка ГМТ с целью обоснования уполномоченным органам принятия положительных решении в предоставлении необходимых, в том числе финансовых стимулов в рамках мер господдержки. Концепцией, разработанной КТГО и ГАК, развитие рынка ГМТ предусматривает синхронизацию газовой и транспортной отраслей экономик [9] и разделено на три кластера.

По первому кластеру, в силу его социальной направленности, предусмотрена синхронизация Плана с «Комплексной программой (Дорожная карта) по развитию автобусных перевозок на 2018 - 2020 годы», где БРК Лизинг обеспечивает финансирование модернизации устаревших и изношенных автобусов. График строительства АГНКС синхронизирован с графиком производства и поставки отечественным автопромом автобусов на газовом топливе - АГНКС строится для якорного потребителя автобусного парка, который обеспечивает окупаемость инвестиции в строительство.

Дорожная карта модернизации автобусных парков в связи завершением календарных сроков действия замещена на «Государственную программу развития туристской отрасли Республики Казахстан на 2019-2025 годы», где также предусмотрены финансовые средства для модернизации автобусных парков.

В целом данная синхронизация способствует окупаемости инвестиции и привлечению инвесторов, в том числе представителей МСБ. Строительство АГНКС в настоящее время в регионах ведут частные компании, привлеченные на условиях предоставления франшизы от ТОО «КазТрансГазӨнимдері», в том числе: ТОО «Akzhayik CNG», TOO «Metan Gas», TOO «SKYMAX TRADE», TOO «AГНКC Казахстан», TOO «AvtoGasServiceCompany».

Для развития второго и третьего кластеров существуют неопределенности по синхронизации развития производственно-сбытовой и потребительской инфраструктуры на МТМ ЕК.

Основные задачи по строительству производственно-сбытовой инфраструктуры на МТМ ЕК и риски

В данном разделе на рисунке 4 представлен анализ основных задач и рисков при реализации проектов строительства производственно-сбытовой инфраструктуры на МТМ ЕК, разделенных на четыре основных блока. 


\section{БУДУЩЕЕ НЕФТЕГАЗОВОГО КОМПЛЕКСА}

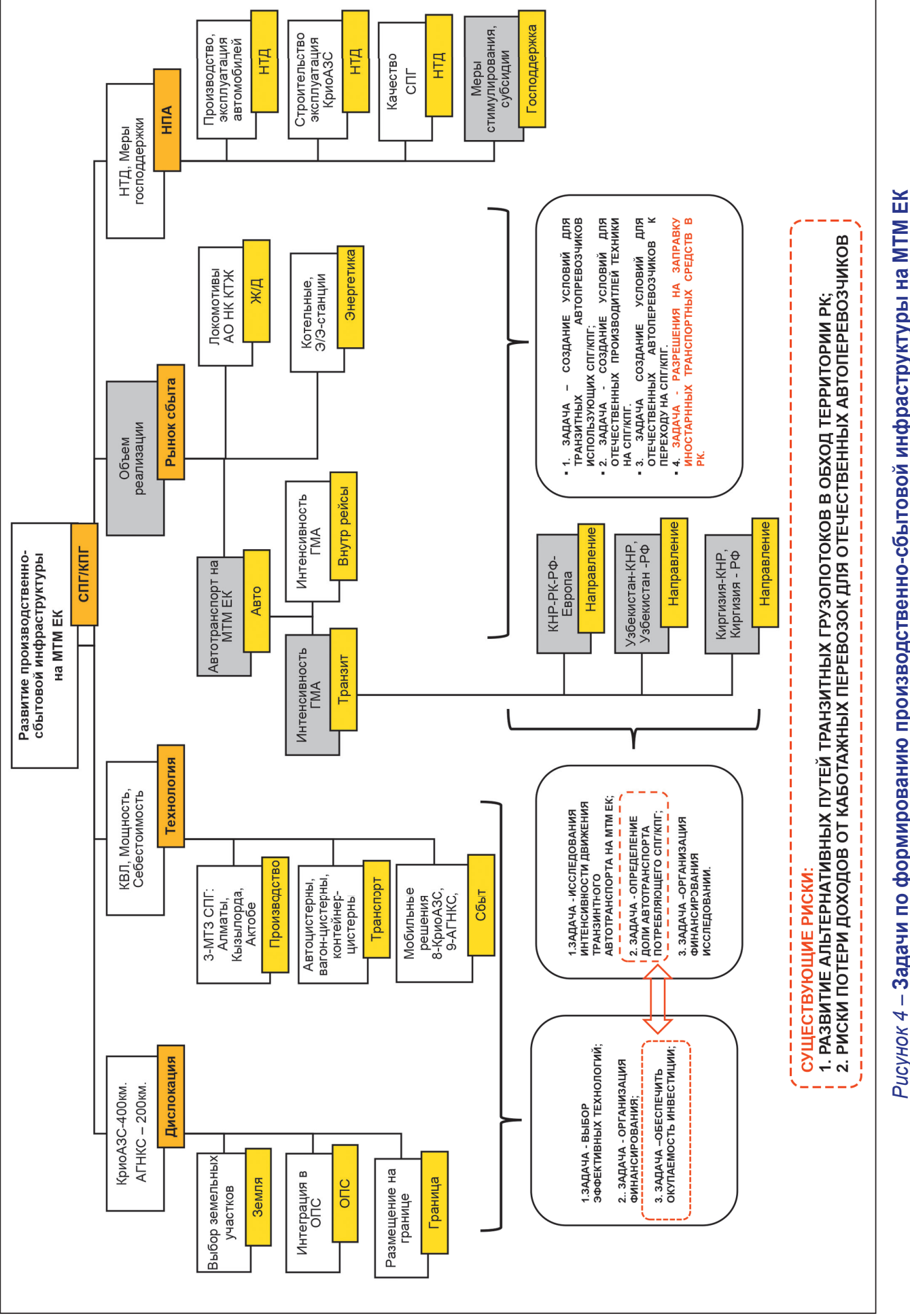




\section{БУДУЩЕЕ НЕФТЕГАЗОВОГО КОМПЛЕКСА}

Блок Дислокация - по результатам международного автопробега, проведенного в рамках Меморандума между ПАО «Газпром», СNPC и АО НК «КазМунайГаз» в сфере развития рынка ГМТ на МТМ «Европа-Китай» принято решение о целесообразности размещения газовых заправок по европейским стандартам: КриоАЗС с шагом 400 км, АГНКС с шагом 200 км на рисунке 5.

В данном направлении между национальным оператором в сфере газа и газоснабжения АО «КазТрансГаз» и $\mathrm{AO}$ «НК «КазАвтоЖол», национальным оператором в сфере эксплуатации автодорог, заключен Меморандум, в рамках которого ведутся работы по отводу земельных участков на МТМ ЕК и других автомагистралях. Также предусматривается интеграция газозаправочной инфраструктуры в объекты придорожного сервиса. В этой связи при содействии АО «НК «КазАвтоЖол» ведутся соответствующие переговоры с владельцами объектов придорожного сервиса (ОПС) (Газэнерджи и Компас). Необходимо отметить, что АО «НК «КазАвтоЖол» разработал очень важную программу по развитию объектов придорожной инфраструктуры, где для инвесторов предусмотрены серьезные меры господдержки.

Блок Технология предусматривает выбор технологии производства транспортировки и реализации СПГ, критериями выбора являются объем капитальных вложений и себестоимость производства СПГ при соответствующей мощности, которая зависит от интенсивности движения газомоторных автомобилей (ГМА). Концепцией КТГО предусмотрено строительство 3-х МТЗ в городах Алматы, Кызылорда и Актобе с учетом эффективного радиуса транспортировки СПГ 500 км. Для транспортировки СПГ предусматривается при каждом МТЗ сформировать парк КриоПАГзов, по укрупненным расчетам его численность для обеспечения МТМ ЕК составит 25-30 ед.

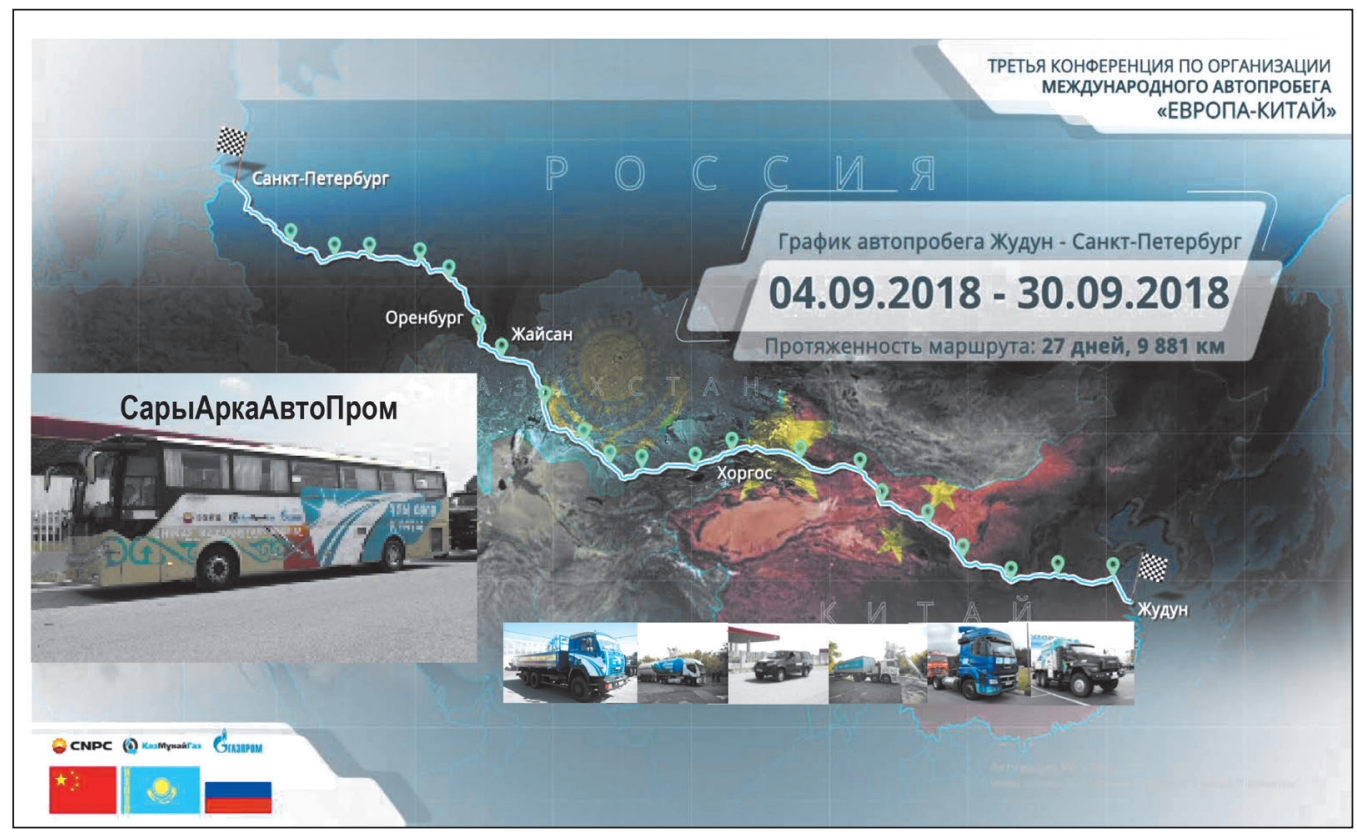

Рисунок 5 - Маршрут международного автопробега газомоторной техники 


\section{БУДУЩЕЕ НЕФТЕГАЗОВОГО КОМПЛЕКСА}

Для реализации СПГ и КПГ планируется построить 8 КриоАЗС по технологии L-CNG и 9 АГНКС с возможностью отбора газа с МГ, а также 4 заправочных терминала для локомотивов АО НК КТЖ.

По блоку Рынок сбыта нами предусмотрено 3 ключевых направления, что диверсифицирует риски, обеспечивающих коммерческую реализацию СПГ и эффективную загрузку МТЗ, при этом не исключается возможность поставки СПГ на экспорт.

1. Направление СПГ-локомотивы. Совместно с АО НК «Казахстан Темир Жолы» реализуется проект по переводу локомотивов на газодизельный режим работы. Рабочей группой, в состав которой входит НИЦ КТП, в рамках Пилотного проекта предусмотрено обоснование соответствующей эффективности, по результатам Пилотного проекта определится годовой объем потребления СПГ.

2. Направление Малая энергетика - предусматривается газификация населения посредством виртуального трубопровода, а также котельных, объектов АПК (зерносушилки) и генерация электроэнергии. В данном направлении предполагается использовать концепцию компании «Global gas group» в г. Нур-Султан.

\section{3. Основное направление - реализация СПГ для автотранспорта на МТМ} $\mathbf{E - K}$, где якорным потребителем предусматривается транзитный грузовой автотранспорт по соответствующим направлениям. Кроме того, в рамках «Плана мероприятий по реализации первого этапа Стратегии экономического развития СНГ на период до 2030 года» узбекской стороной инициированы маршруты автобусных перевозок по МТМ Е-К. Руководству КТГО при встрече с вице-министром транспорта в г. Ташкент было озвучено, что газозаправочная инфраструктура в РК будет дополнительно загружена автотранспортом узбекских автоперевозчиков. Кроме того, на заседании Казахстанско-Татарстанской Рабочей группы по торгово-экономическому сотрудничеству Казахстанская сторона отметила свою готовность положительно рассмотреть вопрос открытия автобусных рейсов по маршрутам «Казань-Шымкент», «Казань-Актау» и возобновление маршрута «Казань-Уральск».

Кроме того, Союз международных автомобильных перевозчиков Республики Казахстан (КазАТО) в обращении в Канцелярию Премьер-Министра заявила о готовности к переходу на СПГ при наличии газозаправочной инфраструктуры и о необходимости соответствующих научно-технических и экономических исследованиях [10].

С учетом вышесказанного по данному блоку необходимо решить следующие задачи:

1. Исследование интенсивности движения транзитного автотранспорта на МТМ ЕК;

2. Определение доли автотранспорта, потребляющего СПГ/КПГ;

3. Организация финансирования исследований.

От полученных результатов зависит возможность дальнейшего привлечения финансирования на проекты строительства производственно-сбытовой инфраструктуры на МТМ ЕК.

По блоку НПА - в рамках деятельности трехсторонних Рабочих групп предусмотрены разработка некоторых нормативно-правовых актов и унификация нормативно-технических документов, направленных на решение задачи создания благопри- 
ятных условий для транзитных автоперевозчиков, стимулов роста отечественным производителям техники на СПГ и отечественным автоперевозчикам, которые желают перейти на использование СПГ/КПГ, путем внесения изменений и корректировок в существующие документы, регулирующие движение международных автоперевозчиков.

Кроме того, одной из основных задач является разработка нормативно-правовых актов по разрешению (допуску) иностранным транспортным средствам заправляться на газовых заправках на территории РК, а отечественным международным перевозчикам на территориях иностранных государств, необходимых для подтверждения безопасного состояния эксплуатируемого на транспорте газобаллонного оборудования.

Все вышеуказанные задачи должны решаться, принимая во внимание: риски развития альтернативных путей в обход территории Казахстана; риски потери доходов отечественными перевозчиками.

На представленном проекте карты дислокации проектируемых и существующих объектов ПСИ на МТМ ЕК (рисунок б) видно, что газификация транспортного сектора экономики РК на первом этапе предусматривается в газифицированных регионах РК. На следующих этапах газификации автодорог инфраструктура будет расширяться и по другим направлениям, указанным на данной карте с учетом возможностей уже существующего/действующего «виртуального газопровода».

Также предусмотрена дислокация малотоннажных заводов по производству СПГ и заправочных терминалов для локомотивного хозяйства АО НК КТЖ. Здесь определены основные расстояния от МТЗ до мест реализации СПГ, что позволит рассчитать себестоимость транспортировки.

Анализ документов, регулирующих транзитные потоки на МТМ Е-К и механизм формирования потоков газомоторной техники на МТМ Е-К.

Из предыдущих разделов следует, что для строительства газозаправочной инфраструктуры по территории Казахстана необходим поток газомоторной техники, т. е. нужен якорный потребитель СПГ. В силу отсутствия автомобилей, потребляющих СПГ у отечественных автоперевозчиков и перевозчиков РФ, им может стать на начальном этапе парк магистральных тягачей КНР, численность которого насчитывает порядка 330 тыс. ед. [11].

Для реализации потенциала якорного потребителя необходимо, чтобы открылись границы для его транзитного движения через территорию Казахстана.

На рисунке 7 представлены некоторые действующие международные документы и нормативно-правовые акты, регулирующие транзитные грузопотоки, и концепция механизма формирования газомоторного потока техники на МТМ ЕК. В настоящее время существует только паритетный обмен квотами на приграничное движение автотранспорта в рамках двусторонних межгосударственных договоров. Соглашением ШОС определены международные автотранспортные коридоры и сроки их запуска, однако, они не задействованы как транзитные грузопотоки автотранспорта КНР через территорию РК. На таможенных приграничных переходах (как Хоргос) осуществляется перегрузка китайских товаров на автотранспорт отечественных, российских и других перевозчиков, имеющих разрешение РК на перевозку груза по территории страны. 


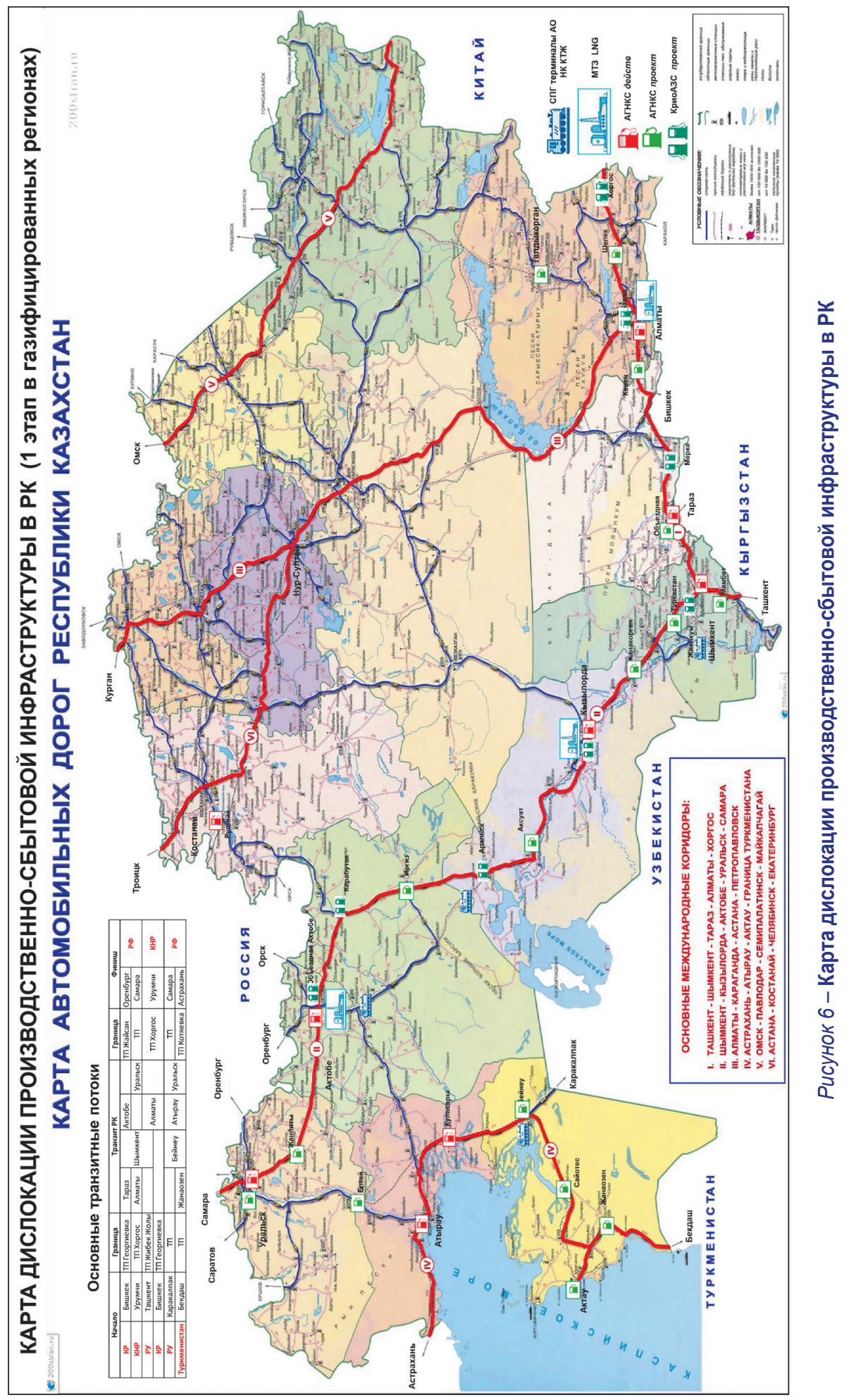




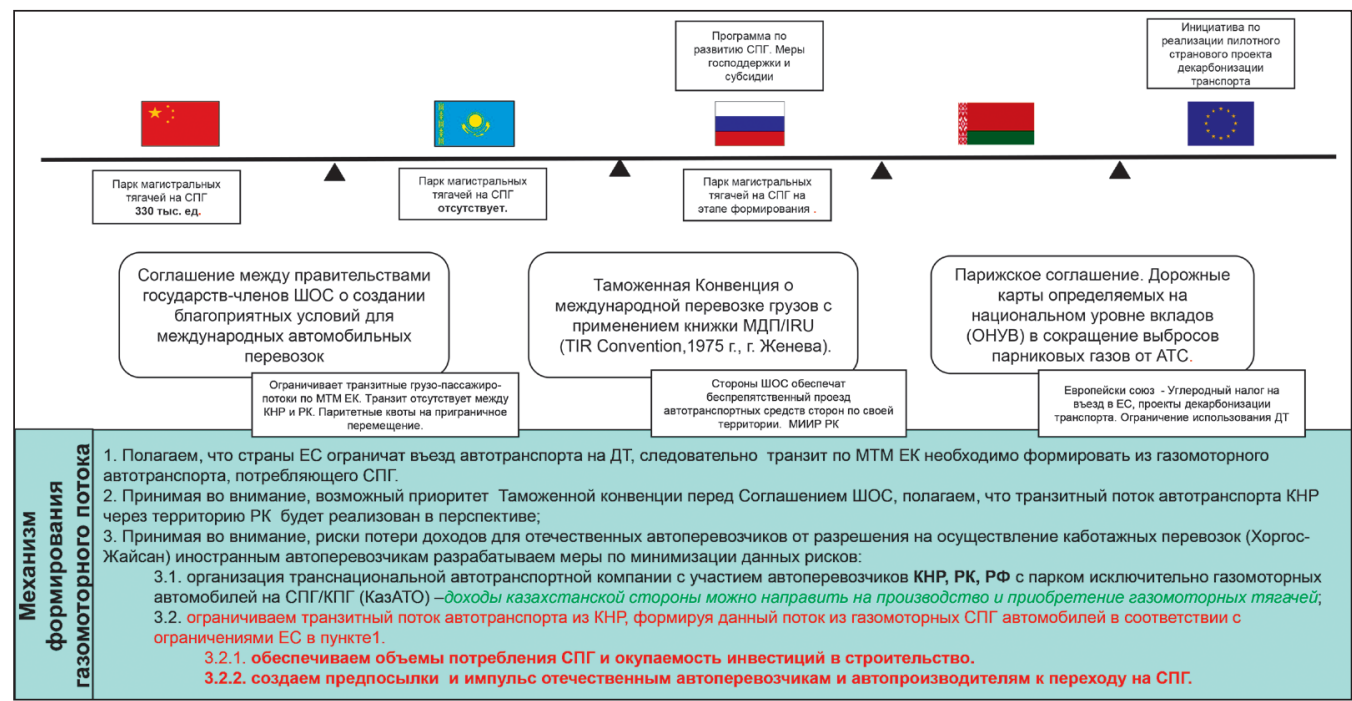

Рисунок 7 - Механизм формирования транзитного потока газомоторной техники на СПГ

При этом на направленный запрос в Департамент развития транзита и транспортной логистики МИИР РК, был получен ответ о том, что в рамках действия Таможенной Конвенции страны ШОС обеспечат беспрепятственный проезд автотранспортных средств сторон по своей территории.

Необходимо учесть, что политика стран Европейского Союза предусматривает ужесточение требований к использованию дизтоплива на транспорте вплоть до ограничения на их въезд на территорию $\mathrm{EC}$, в связи с принятием обязательств по Парижскому соглашению 2015 года.

Реализации вышеуказанной концепции «механизма формирования газомоторного потока» должна обеспечивать минимальные объемы потребления СПГ для окупаемости инвестиции в строительство газовых заправок, но необходимо провести аналитические исследования НПА и решить определенные задачи по подготовке рекомендации по внесению в них соответствующих изменений, и обосновать их эффективность математическими методами расчета (рисунок 8).

Особенности транзитного потока из сопредельных Казахстану стран предполагают однозначное участие в данных исследованиях отраслевых НИИ КНР и РФ и/или консалтинговых компаний, имеющих опыт и международный авторитет в данной области. Это необходимо для согласования и подтверждения потоков газомоторной техники, обеспечения объективности и высокого качества исследований для международных финансовых институтов. Планируется привлечение к данной работе от казахстанской стороны авторитетных научных коллективов в лице НИИ Транспорта и Коммуникации, Сатбаев Университет и Национальный Исследовательский центр комплексных транспортных проблем.

Для проведения вышеуказанных совместных исследовании и обеспечения взаимодействия между институтами необходимо сформировать компетентную и авторитетную организационную структуру международного уровня. 


\section{БУДУЩЕЕ НЕФТЕГАЗОВОГО КОМПЛЕКСА}

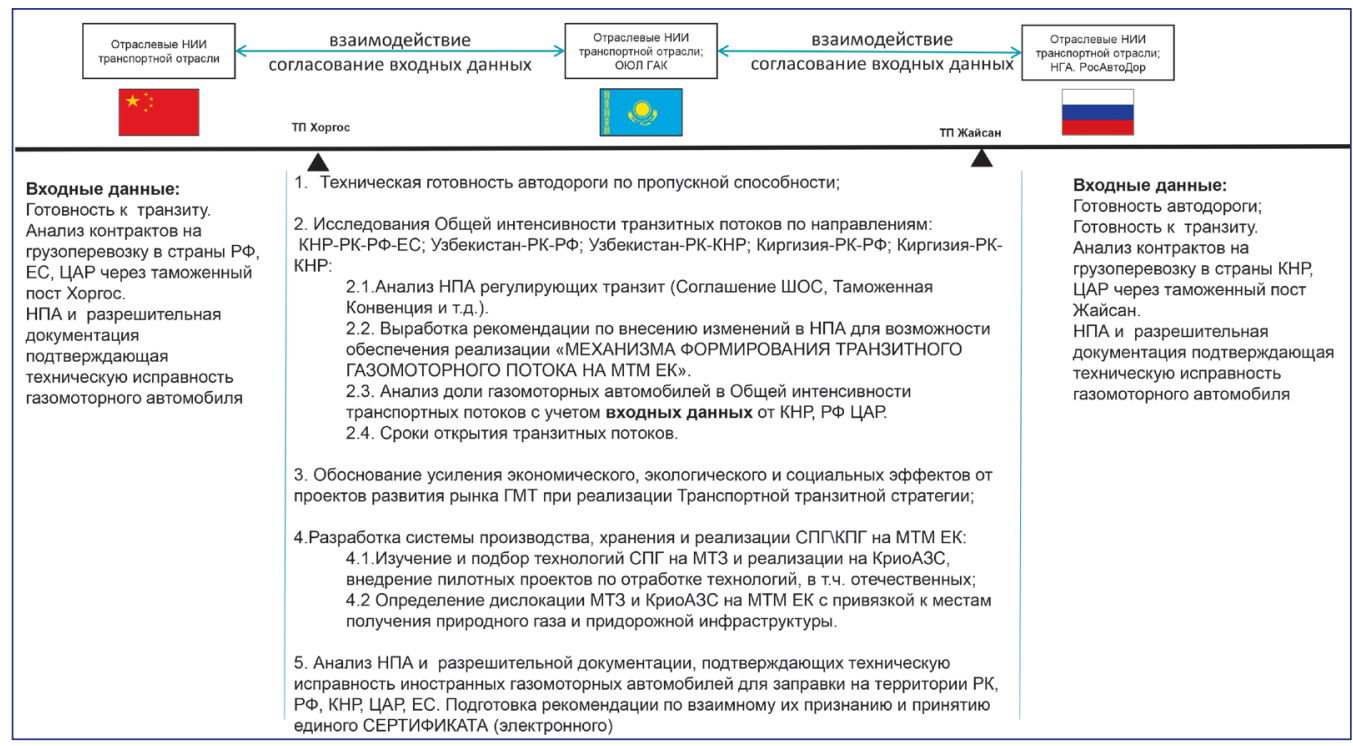

\section{Рисунок 8 - Задачи и направления исследования}

В связи с этим казахстанской стороной в соответствии с положениями 3-х стороннего Меморандума на очередном заседании Совместной рабочей группы в декабре 2020 г. предложено российской и китайской сторонам сформировать Дорожную карту по реализации полномасштабного международного проекта строительства производственно-сбытовой инфраструктуры природного газа в качестве моторного топлива по территории РК, привлечь для проведения совместных исследований интенсивности движения транзитной техники отраслевые институты по аналоги с проектом «Модальное шоссе» МДП/IRU [12], где также были предусмотрены

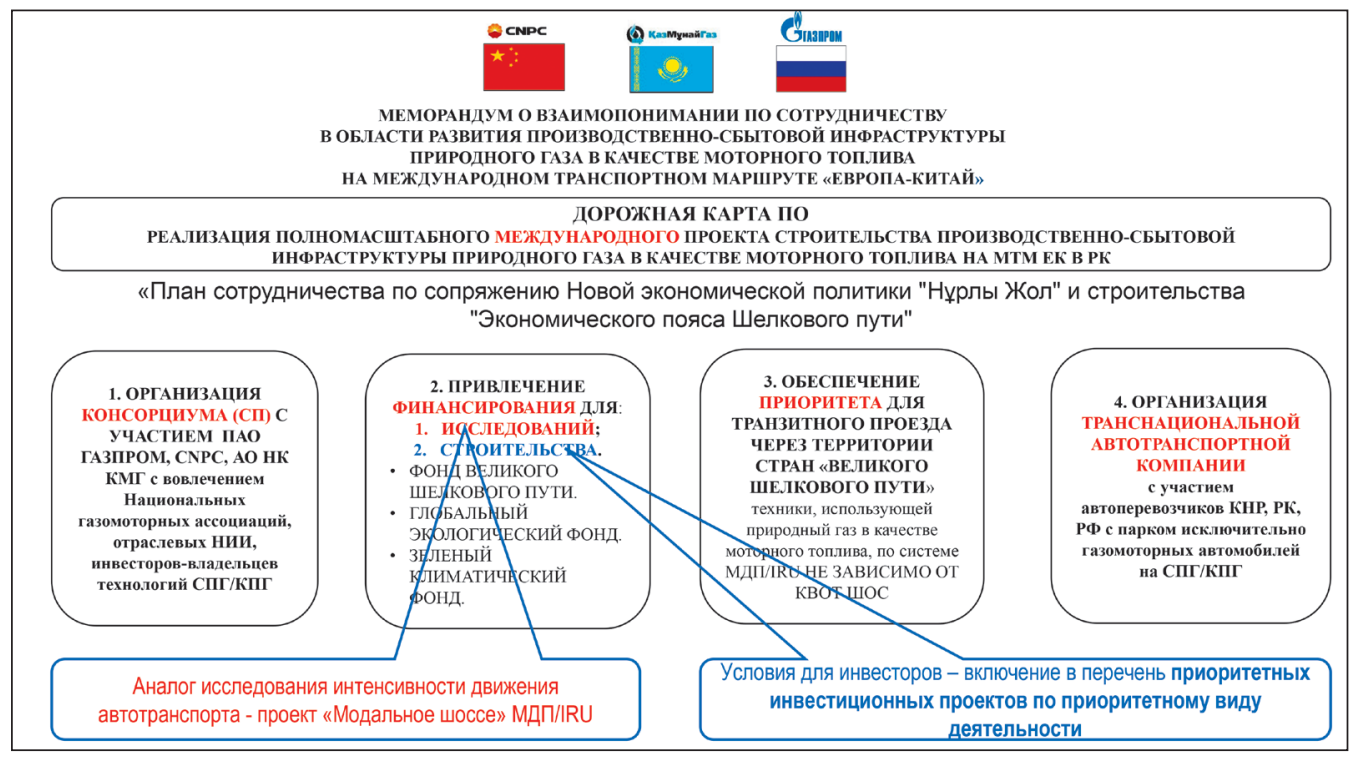

Рисунок 9 - Предложения Казахстанской стороны 


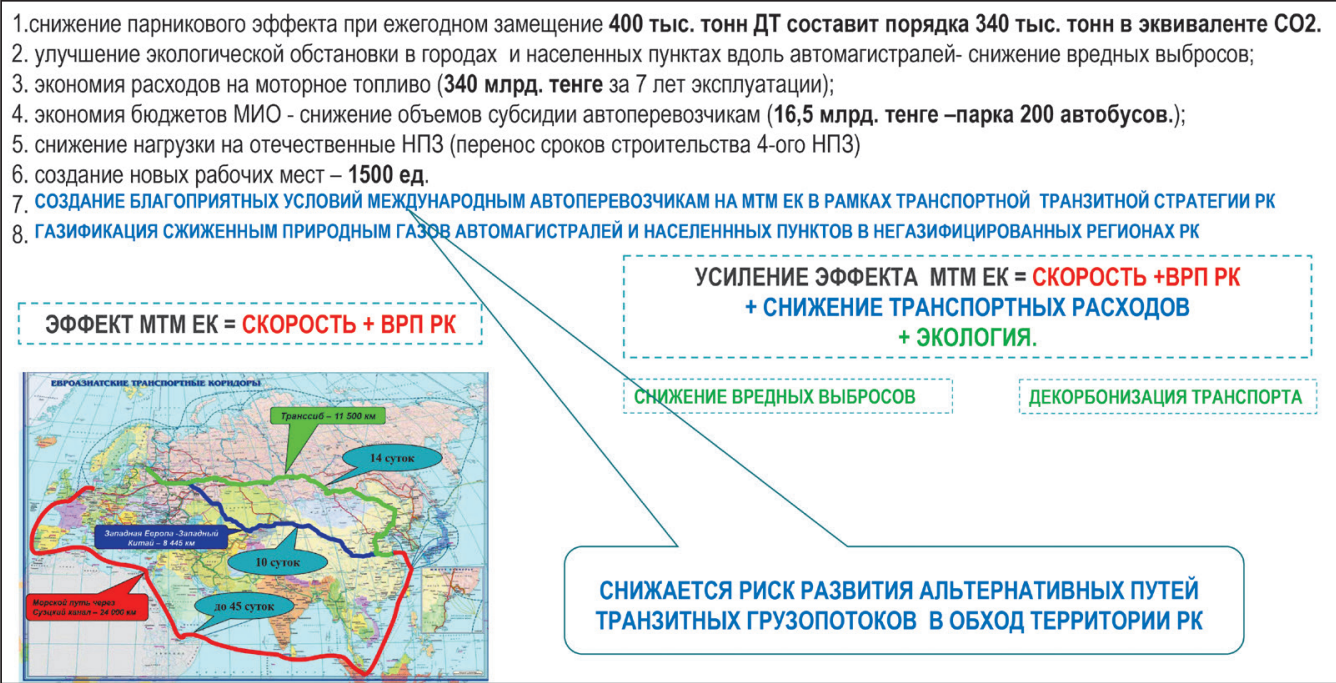

Рисунок 10 - эффекты от развития рынка газомоторного топлива

инициативы о необходимых институциональных преобразованиях в сфере международных перевозок и процедур пересечения границ, в котором участвовал НИИ ТК, с условием предоставления инвестиционных преференции участникам проекта в соответствии с Предпринимательским кодексом РК (рисунок 9).

Необходимо также отметить, что ОЮЛ «Газомоторной ассоциацией Казахстана» на заседании комиссии ЕЭК ООН в рамках Проекта Европейской экономической комиссия ООН «Улучшение возможностей стран-членов ЕЭК ООН по декарбонизации транспортного сектора за счет увеличения использования природного газа в качестве моторного топлива» предложена возможность реализации «Пилотного проекта» по территории РК.

\section{Эффекты от развития рынка газомоторного топлива в РК}

Эффективность транспортной транзитной стратегии [13] подтверждена строительством самой автомагистрали, которая обеспечит скорость транспортировки грузов 10 суток по сравнению с другими направлениями (транссибирская магистраль 14 суток и морской путь через Суэцкий канал 45 суток), и будет сопровождаться увеличением валового регионального продукта от развития МСБ вдоль дороги (рисунок 10).

Но снижение транспортных расходов при замещении ДТ экономичным сжиженным природным газом способствует усилению данного эффекта - увеличению привлекательности для транзитных международных и отечественных автоперевозчиков. При этом экологичность природного газа способствует снижению заболеваемости населения вдоль данной автомагистрали, а также обеспечивает реальное снижение парникового эффекта.

\section{ВЫВОДЫ И ПРЕДЛОЖЕНИЯ}

1. Создание производственно-сбытовой инфраструктуры на «Международном транспортном маршруте «Европа-Китай» для обеспечения транзитного и местно- 


\section{БУДУЩЕЕ НЕФТЕГАЗОВОГО КОМПЛЕКСА}

го автотранспорта экономичными сжиженным и компримированным природным газом способствует усилению эффектов при реализации Транспортной транзитной стратегии РК в части увеличения объема транзитных грузоперевозок и торгового взаимодействия Казахстана с другими странами, снижения себестоимости транспортировки грузов, роста экономического развития регионов и уменьшения экологической нагрузки населенных пунктов вдоль автомагистралей, повышения авторитета страны в связи с реализацией стратегии низкоуглеродного развития транспортного сектора РК.

2. Реализация проектов развития рынка ГМТ в РК всесторонне, географически и концептуально соответствует и гармонизирует инициативе «Один пояс - один путь», Плану сотрудничества по сопряжению Новой экономической политики «Нұрлы Жол» и строительства «Экономического пояса Шелкового пути».

В связи с вышеуказанным считаем чрезвычайно актуальным и важным для развития рынка ГМТ в Казахстане, укрепления международного сотрудничества и конкурентоспособности нашего государства, подтверждение указанных возможных социальных, экономических, экологических и других эффектов, достигаемых благодаря газификации транспорта, путем организации соответствующих научных исследований с привлечением финансирования из авторитетных международных институтов развития, поддерживающих инфраструктурные проекты, сокращающие углеродную составляющую, как, например:

- фонда Великого Шелкового пути,

- Глобального экологического фонда,

- Зеленого климатического фонда.

Это финансовая поддержка будет направлена на проведение научных исследований для:

- изучения интенсивности движения автотранспорта по МТМ ЕК, в том числе для определения доли автотранспорта, потребляющего природный газ в качестве моторного топлива;

• анализа и подготовки предложений по внесению изменений и дополнений в действующие НПА и разрешительную документацию по формированию потока газомоторных автомобилей по МТМ ЕК;

- обоснования усиления экономического, экологического и социальных эффектов от осуществления проектов развития рынка ГМТ на экономику РК, в том числе при реализации транспортной транзитной стратегии;

- реализации возможности трансфера новых инновационных технологий сжижения, хранения, транспортировки и выдачи СПГ для создания устойчивой инфраструктуры обеспечения топливом транзитного и отечественного автотранспорта на MTM EK.

- Осуществления возможности установки региональных экологических индикаторов для верификации вредных выбросов и парниковых газов от транспортного сектора экономики РК и предоставления отчетности в уполномоченные органы РК по изменению климата. 


\section{ЛИТЕРАТУРА}

1 Транспортная стратегия РК до 2020 года (Постановление Правительства Республики Казахстан от 31 января 2005 года № 75) [Transportnay strategya Respubliki Kazahstan 2020 goda (Postanovlenie Pravitel'stva Respubliki Kazahstan ot 31 yanvorya 2005, № 75)]

2 Концепции по развитию газового сектора РК до 2030 года (Утверждена постановлением Правительства Республики Казахстан от 5 декабря 2014 года № 1275) [Contseptsii po razvitiyu gazovogo sektora RK do 2030 goda (Utverzhdena postanovleniem Pravitel'stva Respubliki Kazahstan ot 5 dekabrya, 2014 № 1275)]

3 Абыкаев Н.А. Первый вице-президент Международной академии наук Шелкового пути. Форум мэров городов стран Шелкового пути Global Silk road «Вечерняя Астана» 05.07.2018 [Abykaev N.A. Pervyy vise-prezident Mezhdunarodnoy akademii nauk Shelkovogo puti. Forum merov gorodov stran Shelkovogo puti Global Silk road Vechernyy Astana 05.07.2018]

4 Надиров Н.К. Будущее рационального использования всех видов природного газа // Нефть и газ. - 2018. - №3. - C. 94-97. [Nadirov N.K. Budushee ratsional'nogo ispol'zovaniy vsekh vidov prirodnogo gaza // Neft' i gaz. - 2018. - №3. - P. 94-97]

5 Автайкина Э. Э. Инновации в газовой отрасли. Газомоторное топливо - инновационное направление для российской экономики// Novalnfo.Ru - №26, 2014 г. [Avtaykina E. E. Innovatsii v gazovoy otrasli. Gazamotornoe toplivo - innovastionnoe napravlenie dly rossiyckoy ekonomiki// Novalnfo.Ru - №26, 2014 g.]

6 Отчет на тему «На пути к экологической чистой промышленности и улучшенному мониторингу качества воздуха в Казахстане». /Всемирный банк и Министерство окружающей среды и водных ресурсов Казахстана. 2013 г.)/. [Otchet na temu «Na puti k ekologbcheskoy chistoy promychlennosti i uluchshennomu monitoring kachestva vozdukha v Kazahstane». Nsemirniy bank I Ministerstvo okruzhayushcheyy sredy i vodnykh resursov Kazahstana. 2013 g.]

7 Экологическая эффрективность производства и использования природного газа на основе оценки полного жизненного цикла. УДК 613.1:622.279, О.Е. Аксютин, ПАО «Газпром» (Санкт-Петербург, РФ) А.Г. Ишков, ПАО «Газпром» К.В. Романов, ПАО «Газпром» Н.Б. Пыстина, ООО «Газпром ВНИИГАЗ» (Москва, РФ) Г.С. Акопова, ООО «Газпром ВНИИГАЗ», G_Аkopova@vniigaz.gazprom.ru E.В. Косолапова, ООО «Газпром ВНИИГАЗ» (Москва, РФ). [Ekologicheckayu effektivnost' proizvodstva $\mathrm{i}$ ispol'zovaniy prirodnogo gaza na osnove otsenki polnogo zhiznennogo tsikla. UDK 613.1:622.279, O.E. Aksytin PAO «GazProm» (Sankt - Peterburg, RF) A. G. Ishkov, PAO «GazProm» K.V. Romanov, PAO «GazProm» N.B. Pystina OOO «GazProm VNIIGAZ» (Moscva, RF) G.S. Acopova, «GazProm VNIIGAZ» (Moscva, RF).]

8 Финько В.В., Финько В.Е., Мерпеисов Т.Х. Автомобильные газонаполнительные компрессорные станции для одновременной заправки сжатым и сжиженным природным газом // Нефтьь и газ. - 2017. - №2. - C. 146-153. [Fin’ko V.V., Fin'ko V.E., Merpeisov T.Kh. Avtomobl'nye gazonapolnitel'nye kompressornye stantsii dlya odnovremennoy zapravki szhatym b szhizhennym prirodnym gazom // Neft' i gaz. - 2017. - №2. - P. 146-153.]

9 Арыстанбаев Т.С., Аширов А.С., Климов П.В. Шелковый путь - экологичный транспорт // Нефть и газ. - 2018. - №6. - C. 103-116. [Arystanbaev T.S., Ashirov A.S., Kalimov P.V. Shelkovyy put' - ekologichnyy transport // Neft' i gaz. - 2018. - №6. - C. 103-116.]

10 Письмо исх. №81 от 31.01.2020 г. Союза международных автомобильных перевозчиков Республики Казахстан (КазАТО) «О мерах по расширению применения при- 


\section{БУДУЩЕЕ НЕФТЕГАЗОВОГО КОМПЛЕКСА}

родного газа» в Канцелярию Премьер-Министра РК вх.№434 от 03.02.2020 г. [Pis'mo iskh.№81 ot 31.01.2020 g. Soyuza mezhdunarodnykh avtomobl'nykx perevozkhikov Respubliki Kazahstan (KazATO) «O merakh po rasshireniyu primeneniya prirodnogo gaza» v Kantselyariyu Prem'er-Ministra RK vkh.№ 434 от 03.02.2020 g.]

11 Протокол третьего совещания по реализации трехстороннего Меморандума и организации автопробега газомоторной техники по международному транспортному маршруту «Европа-Китай» ПАО Газпром, Китайской Национальной Нефтегазовой Корпорацией (CNPC) и АО НК КазМунайГаз от 10-12.07.2018 г. Алматы, РК [Protokol tret'ego soveshchaniya po realizatsii thekhstoronnego Memoranduma I organizatsii avtoprobege gazamatornoy tekhniki po mezhdunarodnomu transportnomu marshrutu «Evropa-Kitay» PAO «GazProm» Kitayskay Natsional'noy Neftegazovoy Korporatsiey (CNPC) I PAO i AO NK KazMunayGaz jn 10-12.07.2018 g. Almaty, RK]

12 Отчет Международного союза автомобильного транспорта (IRU) по инициативе «Модельное шоссе» (MHI) [Otchet mezhdunarodnogo soyuza avtomobl'nogo transporta (IRU) po initsiative «Model'noe shosse» (MHI)]

13 Экономические и социальные эффекты от реализации проекта. Значение проекта «Западная Европа-Западный Китай» в развитии регионов Казахстана. Источник офрициальный сайт проекта: http://www.europe-china.kz/info/86 [Economicheskie i sotsial'nye effecty ot realizatsii proekta. Znachenie proekta «Zapadnaya Evropa- Zapadnyy Kitay» v razvitii regionov Kazahstana. Istochnik ofitsiak'nyy sayt proekta: http://www. europe-china.kz/info/86] 